\title{
KELAYAKAN WISATA ALAM DI MAROON MANGROVE EDU PARK SEMARANG
}

\author{
The Feasibility of Nature Tourism at Maroon Mangrove Edu Park Semarang \\ Novia Putri Tarigan, Frida Purwanti*) dan Boedi Hendrarto \\ *Program Studi Manajemen Sumberdaya Perairan \\ Departemen Sumberdaya Akuatik \\ Fakultas Perikanan dan Ilmu Kelautan, Universitas Diponegoro \\ J1. Prof. Soedharto, SH, Tembalang, Semarang, Jawa Tengah - 50275, Telp/Fax. +6224 7474698 \\ Email : noviaputri.tarigan@gmail.com
}

\begin{abstract}
ABSTRAK
Wisata alam mangrove merupakan salah satu kegiatan yang dapat mendukung konservasi mangrove. Setiap kawasan wisata perlu kajian kelayakan perencanaan pengembangannya. Penelitian lapangan dilaksanakan pada bulan Februari 2017 dengan metode deskriptif. Tujuan utama penelitian untuk menganalisis kelayakan MMEP Semarang sebagai destinasi wisata alam, dengan tujuan antara untuk mengidentifikasi profil dan persepsi pengunjung tentang potensi mangrove dan kelayakan MMEP. Pengumpulan data dilakukan dengan teknik wawancara berdasarkan kuesioner terhadap 50 pengunjung, 6 pengelola dan 4 orang pembina kawasan MMEP Semarang. Observasi dilakukan untuk mengamati biofisik mangrove. Wawancara untuk melihat persepsi berdasarkan hasil pengisian kuisoner dengan 4 skala rating. Penilaian kelayakan dihitung berdasarkan parameter potensi ekologis/biofisik, aksesibilitas, dan fasilitas. Hasil penelitian menunjukkan profil pengunjung didominasi kalangan muda usia 20-25 tahun berasal dari Semarang. Persepsi pengunjung sebagian besar menyatakan MMEP layak untuk dikembangkan. Kelayakan wisata di MMEP masuk dalam kategori S2 (layak) dengan nilai 73,65\%.
\end{abstract}

Kata Kunci: Wisata Alam; Kelayakan; Potensi Ekologis; Aksesibilitas; Fasilitas; Maroon Mangrove Edu Park

\section{ABSTRACT}

Nature tourism mangrove is one of the activities that can support conservation of mangroves. Each tourist area needs a feasibility study for it's development planning. The field research was conducted in February 2017 with descriptive method. The main objective of the study was to analyze the feasibility of MMEP Semarang as a natural tourist destination, with the aims of identifying visitor profiles and it's perceptions. The data were collected by interviewing 50 respondens, 6 management staff and 4 consellor of MMEP Semarang. Observations were made to observe the biophysical mangroves. Interview to see perception based on questionnaires result with 4 rating scales. The feasibility assessment is calculated based on parameter of ecological / biophysical potential, accessibility, and facilities. The result of the multiplication of scores and respondents determines the feasibility grade. The research showed that profile of the visitors dominated by young people aged 20-25 years come from Semarang. Perception of most visitors stated that MMEP is feasible to be developed. The MMEP tourism feasibility categories in S2 (feasible) with value 73,65\%.

Keywords: Nature Tourism; Feasibility; Ecological Potential; Accessibility; Facilities; Maroon Mangrove Edu Park

*) Penulis Penanggungjawab

\section{PENDAHULUAN}

Mangrove merupakan ekosistem wilayah pesisir yang memiliki nilai ekologis, sosial, dan ekonomi. Fungsi ekologis untuk mencegah abrasi, menjaga keanekaragaman hayati, dan sebagai habitat vital berbagai biota sedangkan fungsi sosial dan adalah untuk wisata alam. Menjamin keberadaan dan kesinambungan sumberdaya pesisir perlu dilakukan upaya konservasi wilayah pesisir dengan melakukan konservasi. Kegiatan yang bisa dilakukan untuk mendukung konservasi mangrove adalah wisata alam. Kegiatan pariwisata bermanfaat untuk melindungi dan melestarikan ekosistem hutan mangrove yang merupakan daerah pemijahan, daerah asuhan, dan daerah mencari makan untuk berbagai macam biota. Selain itu juga bermanfaat untuk menyokong pertumbuhan sosial ekonomi masyarakat sekitar, dan juga mempertahankan budaya setempat. Vegetasi hutan mangrove yang terletak di daerah pesisir merupakan keindahan dan keanekaragaman vegetasi yang berbeda dari formasi hutan lainnya. Hutan mangrove disamping keindahan vegetasi penyusunnya, terdapat pula satwa liar dari kelas Aves, Mamalia, dan Reptilia. Satwa liar yang dijumpai mempunyai keunikan dengan penyesuaian kondisi habitatnya (Kustanti dan Yulia. 2011). 
Wisata alam berbasis mangrove mulai banyak dikembangkan di Indonesia, diantaranya hutan bakau di Muara Angke Jakarta, Tarakan, Margomulyo Balikpapan, Kampoeng Nipah, Wanasari Bali, dan Rembang. Destinasi wisata alam mangrove juga mulai berkembang di Semarang dan sudah cukup dikenal oleh masyarakat. Contohnya adalah wisata bahari Morosari di Demak, hutan Mangrove Tapak Tugurejo, dan Maron Mangrove Edu Park atau yang lebih dikenal dengan sebutan MMEP. MMEP merupakan salah satu contoh destinasi wisata alam mangrove yang terdapat di Tlogorejo, kota Semarang, Jawa Tengah. MMEP dikembangkan dan dikelola secara resmi pada tahun 2016 dalam pengawasan PT. Phaphros, Tbk. (RNI Group) yang merupakan sebuah perusahaan bidang farmasi dan telah melakukan penanaman sekitar 15.000 bibit mangrove dari genus Rhizopora. MMEP yang terletak di Pantai Maron dan ujung run way Bandara Ahmad Yani Semarang menjadikan kawasan ini memiliki daya tarik wisata tersendiri.

Setiap kawasan wisata perlu dilakukan pengkajian mengenai status kelayakan wisata agar dapat ditarik kesimpulan apakah wisata tersebut layak untuk dijalankan. Penelitian mengenai kelayakan MMEP sebagai destinasi wisata alam merupakan peluang besar untuk pengembangan wisata alam dan tercapainya upaya konservasi hutan mangrove melalui kegiatan wisata alam di MMEP.

Tujuan utama penelitian ini adalah untuk menganalisis kelayakan MMEP sebagai destinasi wisata alam. Dalam mencapai tujuan utama diperlukan tujuan antara yaitu untuk mengetahui profil pengunjung MMEP Semarang dan untuk mengetahui persepsi pengunjung tentang potensi wisata alam MMEP Semarang.

\section{MATERI DAN METODE PENELITIAN}

\section{Materi dan Metode}

Materi dalam penelitian ini meliputi kondisi potensi biofisik (ekologis) MMEP dan persepsi pengunjung MMEP Semarang yang diambil dari data primer dan data sekunder. Penelitian ini bersifat deskriptif dan data primer diambil dari pengukuran data mangrove di lapangan, observasi atau pengamatan serta wawancara menggunakan kuesioner. Menurut Notoatmodjo (2010), pengamatan atau observasi merupakan suatu prosedur berencana, yang antara lain meliputi melihat dan mencatat jumlah taraf aktivitas tertentu yang ada hubungannya dengan masalah yang diteliti. Selanjutnya menurut Narbuko dan Achmadi (2007), wawancara adalah proses tanya jawab dalam penelitian yang berlangsung secara lisan antar dua orang atau lebih yang bertatap muka mendengarkan informasi secara langsung, sedangkan kuesioner merupakan suatu daftar pertanyaan atau suatu rangkaian pertanyaan mengenai sesuatu hal atau sesuatu bidang. Kuesioner dalam penelitian ini diisi oleh responden dan pengisiannya dilakukan di kawasan wisata MMEP Semarang dengan dipandu penulis. Pertanyaan yang diajukan adalah segala hal atau aspek yang berkaitan dengan program pengembangan wisata alam di MMEP Semarang.

Data sekunder merupakan data yang diperlukan dalam penelitian untuk menunjang data primer. Data ini diperoleh dari informasi pihak pengelola yaitu PT. Phapros (peta lokasi, luas lahan MMEP, program pengembangan, aturan/kebijakan), dan juga studi pustaka untuk lebih memahami perihal data sekunder yang diperoleh.

Responden dalam penelitian ini meliputi 50 orang pengunjung, 6 orang pengelola dan penyedia jasa, serta 4 orang pembina kawasan wisata alam MMEP. Penentuan responden dilakukan berdasarkan tujuan yang ingin diperoleh dari responden (purposive sampling) yaitu teknik pengambilan sampling yang didasarkan pada suatu pertimbangan tertentu yang dibuat oleh peneliti sendiri, berdasarkan ciri atau sifat-sifat populasi yang sudah diketahui sebelumnya (Notoatmodjo, 2010).

Penentuan responden pengunjung dilakukan secara accidental sampling namun dipilih dengan pertimbangan usia yang dianggap telah dewasa. Menurut Notoatmodjo (2010), accidental sampling yaitu pengambilan sampel secara aksidental (accidental) dengan mengambil kasus atau responden yang kebetulan ada atau tersedia di suatu tempat sesuai dengan konteks penelitian, sehingga siapa saja yang kebetulan (insidential) bertemu dengan peneliti dan dianggap sesuai dengan karakteristik sampel yang ditentukan maka akan dijadikan sampel. Penentuan responden pengelola kepada semua anggota kelompok Mekar Tani Lindung (METAL) yang sedang bertugas di lokasi pada saat penelitian. Responden pengelola dan penyedia jasa dalam penelitian ini ditentukan dengan cara sensus. Teknik sensus atau sampel jenuh adalah teknik penentuan sampel bila semua anggota populasi digunakan sebagai sampel (Sugiyono, 2006 dalam Hamali, 2013).

\section{Teknik Pengumpulan Data}

Data untuk profil dan persepsi pengunjung tentang potensi wisata dilakukan di lokasi penelitian dengan menggunakan kuesioner. Survei lapangan dilakukan untuk melihat potensi biofisik mangrove serta kondisi aksesibilitas dan ketersediaan fasilitas. Pengamatan biofisik mangrove dilakukan dengan sampling pada 3 stasiun sepanjang jalur tracking untuk mengukur ketebalan, komposisi jenis, dan asosiasi biota. Data kondisi aksesibilitas dan ketersediaan fasilitas dilakukan dengan bantuan kuesioner. Penentuan skoring untuk kuesioner menggunakan skala Likert dengan 5 tingkatan alternatif jawaban $(0=$ sangat tidak tahu, $1=$ tidak tahu, $2=$ ragu, $3=$ tahu, $4=$ sangat tahu $)$.

\section{Pengujian Kuesioner}

Kuesioner yang dapat digunakan dalam penelitian ini adalah kuesioner yang layak (valid dan reliabel), untuk itu perlu dilakukan uji validitas dan uji reliabilitas menggunakan SPSS for Windows Version 16.00 dengan nilai Coeficient Correlation 0,1. Pengujian validitas bertujuan menilai seberapa cermat suatu tes dapat melakukan fungsi ukurnya. Penggunaan alat ukur yang valid akan membuat data yang diperoleh juga valid. Sebuah pertayaan dapat dikatakan valid jika memiliki korelasi yang tinggi terhadap skor total. Korelasi antara masing-masing indikator terhadap total skor konstruk menunjukkan hasil yang signifikan, maka dapat disimpulkan bahwa masing-masing indikator pertanyaan 
adalah valid (Ghozali, 2011). Uji reliabilitas digunakan untuk mengetahui seberapa besar suatu alat ukur dapat diandalkan atau dipercaya untuk melakukan pengukuran. Suatu alat ukur yang digunakan dua kali untuk melakukan pengukuran objek yang sama dan hasil yang diperoleh relatif konsisten maka alat pengukur itu dapat dinyatakan reliabel. Variabel dalam kuesioner dinyatakan reliabel atau konsisten apabila nilai Cronbach Alpha > 0,6 (Ghozali, 2011).

\section{Analisis Data}

Berdasarkan jenis data yang dikumpulkan, analisis data dilakukan secara kualitatif dengan mengelompokkan nilai persepsi dari hasil pengisian kuisoner dengan skala rating, dimana nilai $1-2=$ buruk, $3-5=$ cukup, 6-7 = baik, 8-10 = sangat baik. Kemudian dilakukan tabulasi untuk menilai persepsi mengenai kelayakan wisata alam mangrove di MMEP Semarang. Hasil pengelompokkan nilai kemudian ditabulasi untuk menilai kelayakan wisata MMEP.

\section{Analisis Kelayakan}

Analisis kelayakan dilakukan dengan melihat 3 parameter utama/nilai penting yaitu kelayakan ekologis (potensi sebagai obyek wisata, keindahan, kebersihan), aksesibilitas (mencakup sarana transportasi umum, kondisi jalan, keamanan), dan fasilitas/amenitas (mencakup kondisi jalur tracking, fasilitas toilet umum, fasilitas tempat sampah, fasilitas area bersantai/berkumpul) melalui hasil penilaian kuesioner oleh pengunjung. Hasil penilaian kelayakan dihitung dari hasil perkalian skor dengan jumlah responden (Arisandi, et. al., 2014) untuk menentukan kategori kelayakan (Tabel. 1).

Tabel 1. Analisis Kelayakan

\begin{tabular}{|c|c|c|c|c|c|c|}
\hline \multirow[t]{2}{*}{ Parameter } & \multicolumn{3}{|c|}{ Skor $x \sum$ Responden } & \multirow[t]{2}{*}{ Total } & \multicolumn{2}{|c|}{ Penilaian } \\
\hline & 122 & 3 & 4 & & $(\%)$ & Kriteria \\
\hline $\begin{array}{l}\text { 1. Potensi biofisik (ekologis) } \\
\text { - Potensi sebagai objek wisata } \\
\text { - Keindahan } \\
\text { - Kebersihan }\end{array}$ & & & & & & \\
\hline $\begin{array}{ll}\text { 2. } & \text { Aksesibilitas } \\
- & \text { Kemudahan transportasi } \\
\text { - } & \text { Kondisi jalan } \\
- & \text { Keamanan sepanjang jalan }\end{array}$ & & & & & & \\
\hline $\begin{array}{ll}\text { 3. } & \text { Fasilitas } \\
\text { - } & \text { Kondisi jalur tracking } \\
\text { - } & \text { Kondisi toilet } \\
\text { - } & \text { Ketersedian tempat sampah } \\
- & \text { Ketersediaan fasilitas bersantai / } \\
& \text { tempat duduk }\end{array}$ & & & & & & \\
\hline
\end{tabular}

Keterangan :

Nilai total maksimum : 200

S1 (sangat layak) = dengan nilai $80-100 \%(160-200)$

S2 (layak) = dengan nilai $65-<80 \%(130-<160)$

S3 (cukup) = dengan nilai $35-<65 \%(70-<130)$

$\mathrm{N}$ (kurang layak) = dengan nilai $<35 \%(<70)$

Nilai maksimum diperoleh dari perkalian jumlah responden (50) dengan skor tertinggi (4), diperoleh nilai maksimum sebesar 200. Langkah selanjutnya adalah analisis deskriptif yang dilakukan dengan menggunakan program SPSS for Windows Version 16.00 untuk melihat kesesuaian hasil penilaian kelayakan dari analisis kelayakan dan hasil penilaian secara deskriptif. Data hasil penilaian kelayakan (\%) diinput dalam program kemudian dilakukan analisis deskriptif untuk melihat tendensi nilai mean dan median. Data yang baik adalah jika nilai mean dan median yang diperoleh berhimpit/ hampir sama.

\section{HASIL DAN PEMBAHASAN \\ Deskripsi Lokasi MMEP}

MMEP merupakan destinasi alam mangrove yang terletak di wilayah Lanumad Ahmad Yani, kota Semarang, Jawa Tengah, tepatnya di kawasan pantai Maron dan ujung run way Bandara Ahmad Yani Semarang. Kawasan yang ditempati oleh MMEP adalah milik Kodam IV Diponegoro dibawah pengawasan Lanumad dan merupakan kawasan bebas terbatas karena bersinggungan langsung dengan Bandara Ahmad Yani.

Secara geografis terletak di $6^{\circ} 57^{\prime} 30.03^{\prime \prime} \mathrm{LS}$ dan $110^{\circ} 21^{\prime} 38.65^{\prime \prime} \mathrm{LU}$ dengan suhu udara kawasan ini berkisar antara $30^{\circ} \mathrm{C}-37^{\circ} \mathrm{C}$ serta ketinggian antara $0-15 \mathrm{~m}$ diatas permukaan laut. Kawasan ini berjarak sekitar $11 \mathrm{~km}$ dari pusat kota Semarang dengan jarak tempuh 40 menit serta jalan tanggul dari tanah yang dapat dilalui dengan menggunakan kendaraan pibadi yaitu mobil dan motor.

Sejarah awal hutan mangrove MMEP diawali pada tahun 2011 dimana PT. Phapros, Tbk dan Pemerintah Provinsi memiliki komitmen untuk melestarikan wilayah pesisir sebagai tanggungjawab sosial dari PT. Phapros melalui CSR (Company Social Responsibility). Bentuk tanggungjawab yang dilakukan dengan melakukan penanaman mangrove di wilayah pantai Maron, sejak bulan Februari tahun 2011 PT. Phapros telah bekerjasama dengan Lanumad Ahmad 
\#

Yani untk program penanaman mangrove dan hingga tahun 2016 telah ditanam sebanyak 500.000 bibit mangrove genus Rhizopora oleh PT. Phapros.

MMEP sebagai destinasi wisata mangrove telah menyediakan berbagai fasilitas untuk mendukung aktifitas pengunjung dalam menikmati hutan mangrove, diantaranya jalur tracking dengan panjang keseluruhan 250 meter, 1 gardu pandang tingkat 3,3 gazebo kecil, 1 gazebo apung, 1 aula pertemuan, 1 mushola, 2 toilet, 1 perahu, dan tempat parkir. Jalur tracking dalam waktu dekat akan ditambah sepanjang 300 meter.

1. Ketebalan Mangrove dan Kerapatan Mangrove

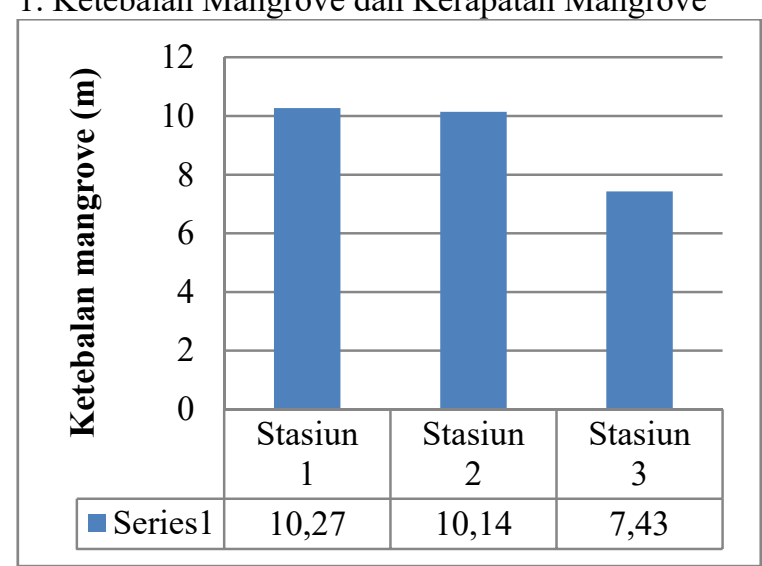

Gambar 1. Diagram ketebalan mangrove di 3 stasiun di kawasan MMEP Semarang

Februari 2017

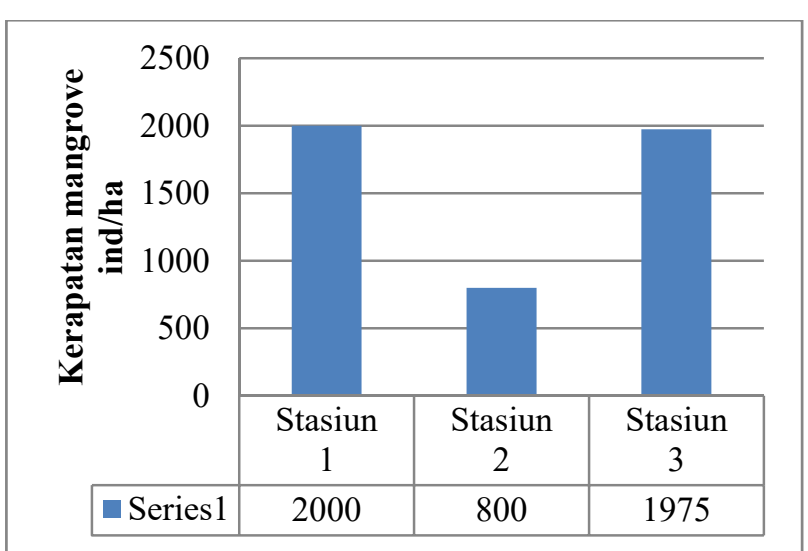

Gambar 2. Diagram kerapatan mangrove di 3 stasiun di kawasan MMEP Semarang

Sumber : Sinaga (2017)

Berdasarkan Gambar 1. di atas diketahui bahwa stasiun 1 memiliki ketebalan tertinggi dan stasiun 3 memiliki ketebalan terendah. Ketebalan mangrove pada kawasan MMEP tergolong rendah karena kawasan ini bukan merupakan hutan mangrove asli melainkan sengaja ditanam untuk keperluan wisata alam, hutan yang terlalu tebal akan menyulitkan pengunjung dalam berwisata. Selain itu rendahnya ketebalan juga dikarenakan usia mangrove yang tergolong masih muda yaitu 5 tahun. Hal ini diperkuat oleh penelitian Firmansyah et. al., (2016), bahwa ketebalan mangrove di kawasan wisata lain bisa mencapai ketebalan hingga $67 \mathrm{~m}$ dan ketebalan terendah yaitu $38 \mathrm{~m}$.

Berdasarkan Gambar 2 di atas diketahui bahwa titik 1 memiliki kerapatan tertinggi dan titik 2 memiliki kerapatan terendah. Perbedaan kerapatan yang signifikan pada titik 2 disebabkan karena intensitas penanaman di titik tersebut kurang, selain itu juga dipicu oleh antropologi (aktifitas manusi) yang sering melakukan kegiatan di sekitar titik tersebut misalnya untuk tempat bersandar kapal. Titik 1 dan 3 sudah termasuk dalam kriteria baik. Hal ini menunjukkan bahwa upaya rehabilitasi dan konservasi yang dilakukan pihak pengelola melalui wisata alam dapat dikatakan berhasil. Menurut Kepmen. LH No. 201 tahun 2004, kerapatan mangrove di kawasan MMEP tergolong dalam kriteria baik (sangat padat).

\section{Komposisi Jenis Mangrove}

Berdasarkan hasil identifikasi yang dilakukan di lapangan dijumpai 2 jenis mangrove yaitu Bakau (Rhizopora muncronata) dan Api-api (Avicennia marina), namun di stasiun sampling dari stasiun I sampai stasiun III hanya dijumpai mangrove jenis Bakau (R. muncronata). Jumlah mangrove yang mendominasi adalah jenis Bakau ( $R$. muncronata). Pada ke 3 stasiun pengamatan sepanjang jalur tracking hanya dijumpai $R$. muncronta sedangkan $A$. marina masih dalam proses penyemaian. Hal ini disebabkan pada awal proses rehabilitasi yang dilakukan di wilayah pantai Maron, pihak pengelola hanya menanam jenis bakau karena kondisi salinitas yang rendah dan cocok dengan jenis Bakau (R. muncronata). Menurut penelitian Simanjuntak (2013), dominasi oleh jenis R. apiculata juga disebabkan oleh mudahnya propagul jenis tersebut tumbuh dan didukung oleh daur hidup yang khusus dari jenis bakau tersebut dengan benih yang dapat berkecambah pada masih berada pada induk sehingga sangat mendukung pada proses distribusi yang luas dari jenis tersebut. Pada tingkat pohon jenis yang mendominasi adalah tanaman bakau. Banyaknya indukan pohon bakau yang mendominasi ini dapat sebagai penghasil sebaran biji dalam jumlah yang banyak sehingga penyebaran biji, cukup mengasilkan distribusi yang luas tingkat semai dan tingkat pancang yang luas pula dari jenis tersebut.

3. Asosiasi Biota

Biota yang ditemukan di wilayah MMEP berdasarkan informasi nelayan pancing dan pemilik tambak adalah ikan Bandeng (Chanos chanos Forska), ikan Kakap (Lutjanidae sp.), udang Putih (Fenneropenaeus indicus), udang Windu (Penaeus monodon), burung Dederuk jawa (Streptopelia biturquata), burung Pekukur (Spilopelia chinensis), burung Tledekan laut (Cyanoptila cyanomelana), blekok sawah (Ardeola specioasa), Bangau (Ciconiidae sp.), Tiram (Ostreidae sp.), kepiting Bakau (Scylla serrata), dan Ular sawah (Python reticulatus). Keberadaan beberapa fauna akan menjadi daya tarik tersendiri bagi pengunjung untuk mengunjungi suatu kawasan wisata. Menurut Sitepu et. al., (2015), keberadaan fauna khas di kawasan wisata lain sebagai contoh burung Bangau Putih Susu di Desa Denai Kuala menjadi daya tarik tersendiri karena sebelumnya fauna ini tidak ditemukan di desa tersebut. Biota khas yang jarang ditemui dapat menjadi pemandangan yang menarik bagi wisatawan.

\section{Pengujian Kuesioner}

\section{Uji Validitas}

${ }^{\circ}$ Copyright by Management of Aquatic Resources (MAQUARES) 
Berdasarkan hasil pengujian kuesioner menggunakan program SPSS 16.0 masing-masing variabel dapat dilihat pada tampilan output Lampiran 3 menunjukkan bahwa korelasi antara beberapa indikator yakni A1; A6; A8; B10; B11; B12; B14; C15; C17; C18; C19; D22; D23; D24; D25; D26; D27; D28 terhadap total skor konstruk menunjukkan hasil yang signifikan atau dapat dikatakan bahwa ke-18 indikator pertanyaan tersebut adalah valid. Hal ini sesuai dengan pendapat Ghozali (2011), bahwa apabila korelasi indikator terhadap total skor konstruk signifikan, maka indikator tersebut adalah valid.

2. Uji Reliabilitas

Berdasarkan hasil pengujian kuesioner menggunakan program SPSS 16.0 variabel yang diteliti dapat dilihat pada tampilan output lampiran 4 menunjukkan nilai Cronbach Alpha 5,98 Menurut Ghozali (2011), suatu konstruk atau variabel dikatakan reliabel jika memberikan nilai Crombach Alpha > 6,0.

\section{Profil dan Persepsi Pengunjung MMEP Semarang}

\section{a. Profil Pengunjung}

Berdasarkan hasil wawancara terhadap 50 responden diperoleh informasi mengenai profil pengunjung, motivasi berwisata, persepsi mengenai kelayakan ekologis, aksesibilitas dan fasilitas. Profil pengunjung MMEP dapat dilihat pada tabel berikut (Tabel. 2).

Tabel 2. Profil Pengunjung MMEP Semarang, Februari 2017

\begin{tabular}{|c|c|c|c|}
\hline No. & Parameter Pengunjung & Jumlah Responden (orang) & Persentase $(\%)$ \\
\hline \multirow[t]{3}{*}{1.} & Jenis Kelamin & & \\
\hline & - Laki-laki & 24 & 48 \\
\hline & - Perempuan & 26 & 52 \\
\hline \multirow[t]{5}{*}{2.} & Usia (tahun) & & \\
\hline & $-<20$ & 20 & 40 \\
\hline & $-21-25$ & 22 & 44 \\
\hline & $-26-30$ & 6 & 12 \\
\hline & $->30$ & 2 & 4 \\
\hline \multirow[t]{5}{*}{3.} & Pendidikan & & \\
\hline & - SMP & 10 & 17 \\
\hline & - SMA & 29 & 48 \\
\hline & - D3 & 6 & 10 \\
\hline & $-\mathrm{S} 1$ & 15 & 25 \\
\hline \multirow[t]{8}{*}{4.} & Pekerjaan & & \\
\hline & - Pelajar & 4 & 8 \\
\hline & - Mahasiswa & 14 & 28 \\
\hline & - Karyawan & 7 & 14 \\
\hline & - Guru & 4 & 8 \\
\hline & - Buruh & 9 & 18 \\
\hline & - Wiraswasta & 3 & 6 \\
\hline & - Lainnya & 9 & 18 \\
\hline \multirow[t]{3}{*}{5.} & Asal Pengunjung & & \\
\hline & - Semarang & 32 & 64 \\
\hline & - Luar Semarang & 18 & 36 \\
\hline
\end{tabular}

Tingkat pendidikan pengunjung MMEP adalah lulusan SMP sebanyak 10 orang (17\%), SMA sebanyak 29 orang (48\%), Diploma sebanyak 6 orang (10\%), dan Sarjana sebanyak 25 orang (25\%). Data tersebut menunjukkan bahwa pengunjung MMEP paling banyak merupakan lulusan SMA sederajat.

Status pekerjaan pengunjung MMEP sangat bervariasi diantaranya yang masih berstatus pelajar/mahasiswa sebanyak 18 orang (36\%), bekerja sebagai buruh pabrik sebanyak 9 orang (18\%), sebagai karyawan sebanyak 7 orang (14\%), dan lainnya (mencakup guru, wiraswasta, honorer BNN, asisten perawat, PNS, pemilik butik, dan tidak bekerja) sebanyak 16 orang (32\%). Data tersebut menunjukkan bahwa mayoritas pengunjung MMEP berstatus sebagai pelajar/mahasiswa.

Asal/tempat tinggal pengunjung MMEP sangat beragam dari dalam maupun luar kota Semarang. Data kuesioner menunjukkan bahwa pengunjung yang berasal dari Semarang sebanyak 32 orang (64\%) sedangkan dari luar Semarang (mencakup Purwokerto, Purwodadi, Mijen, Jogja, Tegal, Kebumen, Majalengka, Temanggung, Jakarta, Kudus, Blora, Demak, Batang) sebanyak 18 orang (36\%). 


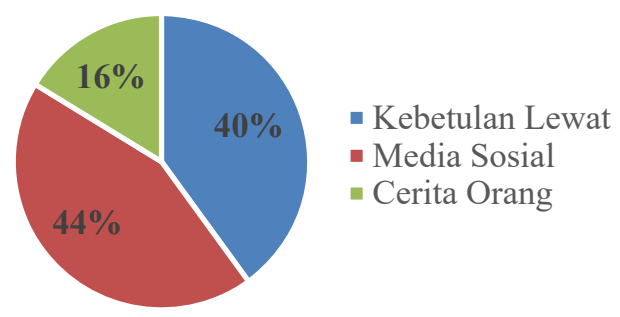

Gambar 3. Sumber informasi

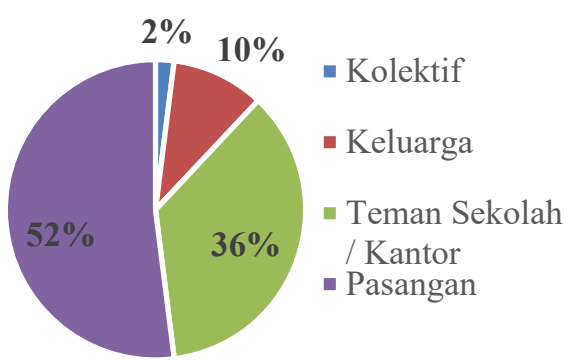

Gambar 4. Model kunjungan

Pengunjung MMEP memperoleh informasi mengenai kawasan tersebut melalui internet dan media sosial sebanyak 35 orang (70\%), dari cerita orang lain sebanyak 13 orang (26\%), dan kebetulan lewat sebanyak 2 orang (4\%). Data ini menunjukkan bahwa sebagian besar pengunjung memperolah informasi mengenai kawasan wisata MMEP melalui internet dan media sosial, hal ini bisa digunakan sebagai salah satu strategi pengenalan kawasan wisata MMEP kepada masyarakat umum secara mudah melalui media sosial. Hal ini sesuai dengan penelitian Umami (2015), bahwa media sosial merupakan media promosi yang lebih intim dan dapat terjadi komunikasi interaktif yang melibatkan antara wisatawan dengan produk-produk pariwisata dan dengan sendirinya dapat meningkatkan awareness. Segmentasi dapat terbentuk dengan munculnya komunitas online. Hubungan baik yang terjalin pada komunitas yang ada maka akan memudahkan pelaku pariwisata memberikan persuasi produk secara kreatif, mendapatkan database, identifikasi pasar potensial sehingga dapat membuat strategi komunikasi selanjutnya.

Pengunjung MMEP melakukan kunjungan secara kolektif/rombongan sebanyak 1 orang (2\%), bersama keluarga sebanyak 5 orang $(10 \%)$, bersama teman sekolah/kantor sebanyak 18 orang $(36 \%)$, dan bersama pasangan sebanyak 26 orang (52\%). Data tersebut menunjukkan bahwa mayoritas pengunjung MMEP melakukan kunjungan bersama pasangan.

\section{b. Persepsi Pengunjung tentang Objek Wisata MMEP}

Tingkat pengetahuan pengunjung MMEP didapatkan sebanyak 22 (44\%) orang menyatakan tahu mengenai fungsi dan manfaat mangrove mangrove sedangkan sebanyak $28(56 \%)$ orang menyatakan tidak mengetahui fungsi dan manfaat mangrove. Data tersebut menunjukkan bahwa mayoritas pengunjung masih belum mengenai apa fungsi dan manfaat mangrove bahkan setelah mengunjungi MMEP. Berdasarkan data tersebut dapat dilihat bahwa MMEP sebagai kawasan edu park belum sepenuhnya memenuhi fungsi utamanya yaitu memberikan edukasi/ pendidikan mengenai mangrove kepada pengunjung. Perlu disusun rencana pemberian edukasi secara langsung (melalui jasa guide) maupun tidak langsung (melalui papan interpretasi). Rencana program interpretasi ditujukan untuk mengelola aktivitas wisata agar dapat sejalan dengan tujuan dan pesan yang akan disampaikan. Aktivitas wisata tersebut hendaknya dapat memberikan pengetahuan dan pengalaman baru bagi pengunjung (Alderson dan Low, 1996 dalam Yusiana dan Mayadewi, 2016). Selanjutnya menurut Black (2000), interpertasi lingkungan dapat berperan penting dalam ekowisata dengan memberikan edukasi kepada pengunjung tentang kawasan yang dikunjunginya, memberikan informasi tentang konsekuensi pada setiap tindakan dan merangsang perilaku pengunjung untuk melestarikan lingkungan.

Harga tiket masuk yang dibebankan kepada pengunjung untuk subsisdi bibit dinilai sebanyak 48 orang (96\%) menganggap sepadan sedangkan 2 orang (4\%) menganggap tidak sepadan. Data ini menunjukkan bahwa sebagian besar pengunjung tidak merasa keberatan untuk membayar tiket masuk sebagai subsidi bibit mangrove.

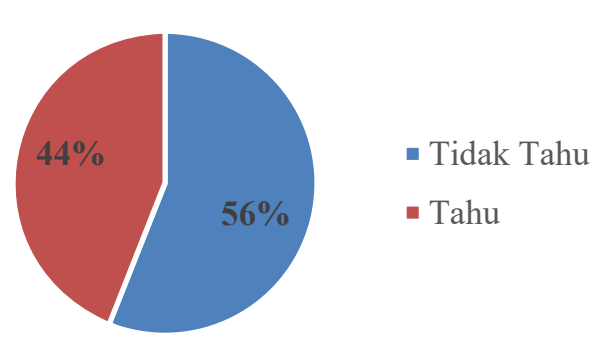

Gambar 5. Pengetahuan mengenai mangrove

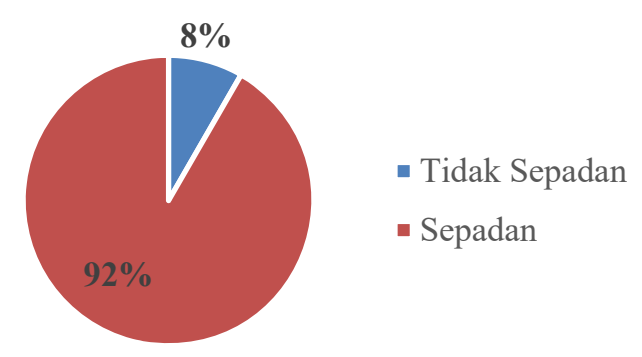

Gambar 6. Persepsi harga tiket

Berdasarkan data kuesioner yang diambil tehadap 50 orang pengunjung, diperoleh informasi bahwa 48 orang (96\%) menyatakan MMEP layak untuk dikembangkan dan 2 orang (4\%) menyatakan bahwa MMEP tidak layak untuk dikembangkan. Persepsi pengunjung didasari akan berbagai hal, diantaranya pengunjung berpendapat bahwa MMEP layak untuk dikembangkan karena kawasan dinilai sejuk dan asri, merupakan satu-satunya destinasi wisata alam mangrove berbasis edukasi untuk menambah wawasan, untuk keperluan pelestarian lingkungan, memiliki potensi yang besar untuk dikembangkan, harga tiket terjangkau untuk wisata kalangan menengah kebawah, masih jarang ditemui kawasan wisata alam mangrove di tengah kota, pemandangan dan tempat yang indah, antusiasme pengunjung cukup tinggi, dan untuk menambah destinasi wisata alam di Semarang. 
Sebagian pengunjung yang menyebutkan MMEP tidak layak untuk dikembangkan memiliki alasan bahwa kawasan MMEP tidak terawat dan masih perlu dilakukan rehabilitasi sebelum dikembangkan/dibuka untuk umum. Kondisi jalan yang terjal, sempit, dan berlumpur merupakan kekurangan yang paling banyak dikeluhkan oleh pengunjung. Kondisi jalan yang licin ketika turun hujan berbahaya bagi pengunjung yang datang menggunakan kendaraan roda dua maupun roda empat, karena dapat menyebabkan terpeleset dan ban mengalami selip. Kegiatan mobil pengangkut dari proyek yang melakukan pembangunan di sekitar kawasan MMEP menyebabkan kondisi jalan semakin parah. Pengunjung menilai perlu dilakukan perbaikan jalan untuk mendukung perkembangan MMEP menjadi lebih pesat. Menurut Slamet et. al., (2015), aksesibilitas penting untuk diperhatikan, hal tersebut dikarenakan aksesibilitas memberikan pengaruh yang cukup besar terhadap kunjungan wisatawan terutama yang berkunjung untuk menikmati suasana alam. Hasil observasi yang telah dilakukan dapat dilihat bahwa, masih banyak jalur aksesibilitas yang berlobang dan jalurnya masih terbilang sempit. Hasil wawancara juga menyebutkan adanya ketidak teraturan antar penggali pasir dalam melakukan pekerjaanya, sehingga perlu kiranya adanya pembenahan bila adanya kerusakan.

Berdasarkan data kuesioner kepada pembina/pendamping kelompok METAL yaitu Yayasan Ikamat dan CSR PT. Phapros, diperoleh kesimpulan bahwa keseluruhan persepsi pembina/pendamping menyebutkan MMEP layak untuk dikembangkan. Alasan yang mendasari persepsi tersebut adalah antusiasme dari kelompok METAL cukup tinggi dan kini mereka lebih peduli terhadap lingkungan, alasan lain adalah mulai mengalinnya bantuan dari berbagai pihak (Pemerintah Kota Semarang maupun organisasi lain) dalam bentuk dana maupun dukungan untuk melakukan penanaman mangrove, serta untuk mengenalkan mangrove kepada masyarakat umum melalui budaya masyarakat sekarang yang mulai sadar pentingnya rekreasi untuk melepas penat serta mengajak generasi muda untuk mengenal dan mencintai mangrove. MMEP sebagai satu-satunya kawasan wisata alam mangrove berbasis edukasi juga menjadi alasan penting yang mendasari MMEP layak untuk dikembangkan, selain untuk mempopulerkan wisata alam khususnya mangrove yang sudah mulai tergerus jaman dan digantikan oleh wisata modern, menambah wawasan dan pengetahuan mengenai pentingnya mangrove, juga untuk keperluan konservasi alam.

Berdasarkan data kuesioner kepada pengelola dan penyedia jasa yaitu kelompok METAL dan pemilik warung, diperoleh kesimpulan bahwa keseluruhan persepsi pengelola dan penyedia jasa menyebutkan MMEP layak untuk dikembangkan. Alasan yang mendasari persepsi tersebut cukup beragam diantaranya MMEP merupakan kawasan yang aman untuk wisata karena berada di bawah pengawasan kodam sehingga tindak kriminalitas sangat minim, MMEP mudah diakses karena terletak di tengah kota/dekat dengan bandara Ahmad Yani, MMEP memiliki potensi yang besar untuk dikembangkan karena dekat dengan daerah wisata lain, bandara baru akan dibangun dan dilengkapi dengan objek wisata dan rumah makan apung sehingga bisa menunjang perkembangan MMEP, MMEP juga merupakan lahan tambahan penghasilan dan membuka lapangan pekerjaan sampingan bagi petani tambak yang pendapatannya sangat menurun paska reklamasi, dan alasan yang terakhir MMEP sebagai sarana pelestarian hutan mangrove. Pengembangan MMEP berdampak positif bagi petani tambak dalam segi ekonomi yaitu menunjang pendapatan, juga dalam segi sosial untuk memperluas sosialisasi dengan masyarakat umum, dan dalam segi pola pikir mengubah persepsi petani tambak untuk lebih mencintai mangrove.

\section{Kelayakan MMEP sebagai Destinasi Wisata Alam}

Kelayakan MMEP sebagai destinasi wisata alam diperoleh berdasarkan penilaian pengunjung terhadap 3 parameter utama yaitu potensi biofisik (ekologis), aksesibilitas, dan fasilitas tersaji pada Tabel 3. berikut Tabel 3. Kelayakan Wisata MMEP

\begin{tabular}{|c|c|c|c|c|c|c|c|}
\hline \multirow[t]{2}{*}{ Parameter } & \multicolumn{4}{|c|}{ Skor $x \sum$ Responden } & \multirow[t]{2}{*}{ Total } & \multicolumn{2}{|c|}{ Penilaian } \\
\hline & 1 & 2 & 3 & 4 & & (\%) & Kriteria \\
\hline \multicolumn{8}{|l|}{ 1. Potensi biofisik (ekologis) } \\
\hline $\begin{array}{l}\text { - Potensi sebagai objek wisata } \\
\text { - Keindahan }\end{array}$ & 0 & 0 & 39 & 148 & 187 & 93,5 & S1 \\
\hline - Kebersihan & 0 & 4 & 69 & 100 & 173 & 86,5 & S1 \\
\hline & 0 & 18 & 72 & 44 & 134 & 67 & $\mathrm{~S} 2$ \\
\hline \multicolumn{8}{|l|}{ 2. Aksesibilitas } \\
\hline - Kemudahan transportasi & 4 & 62 & 36 & 8 & 110 & 55 & $\mathrm{~S} 3$ \\
\hline - Kondisi jalan & 1 & 80 & 27 & 0 & 108 & 54 & $\mathrm{~S} 3$ \\
\hline - Keamanan sepanjang jalan & 1 & 22 & 78 & 48 & 149 & 74,5 & $\mathrm{~S} 2$ \\
\hline \multicolumn{8}{|l|}{ 3. Fasilitas } \\
\hline - Kondisi jalur tracking & 0 & 14 & 81 & 64 & 159 & 79,5 & $\mathrm{~S} 2$ \\
\hline - Kondisi toilet & 1 & 32 & 72 & 36 & 141 & 70,5 & $\mathrm{~S} 2$ \\
\hline - Ketersedian tempat sampah & 2 & 24 & 81 & 36 & 143 & 71,5 & $\mathrm{~S} 2$ \\
\hline $\begin{array}{l}\text { - Ketersediaan fasilitas bersantai / } \\
\text { tempat duduk }\end{array}$ & 0 & 12 & 57 & 100 & 169 & 84,5 & $\mathrm{~S} 1$ \\
\hline
\end{tabular}




\begin{tabular}{lll}
\hline Rata-rata & 73,65 & $\mathrm{~S} 2$ \\
\hline Modus & & $\mathrm{S} 2$ \\
\hline
\end{tabular}

Keterangan :

Nilai total maksimum : 200

S1 (sangat layak) = dengan nilai $80-100 \%(160-200)$

S2 (layak) = dengan nilai $65-<80 \%(130-<160)$

S3 (cukup) = dengan nilai $35-<65 \%(70-<130)$

$\mathrm{N}$ (kurang layak) $\quad=$ dengan nilai $<35 \%(<70)$

Hasil analisis terhadap parameter potensi biofisik (ekologis) persentase tertinggi variabel pertama yaitu (potensi sebagai objek wisata) sebesar 93,5\% dengan kriteria S1 (sangat layak) dan persentase terendah variabel ketiga yaitu kebersihan sebesar 67\% dengan kriteria S2 (layak). Penempatan dan jumlah tempat sampah tidak sesuai dengan harapan pengunjung, serta kurangnya kesadarana pengunjung untuk ikut menjaga kebersihan kawasan wisata menyebabkan masih terdapat banyak sampah anorganik (plastik, tisu, sandal bekas, botol dan kaleng minuman) yang berserakkan.

Hasil analisis terhadap parameter aksesibilitas persentase tertinggi yaitu variabel keamanan sepanjang jalan sebesar 74,5\% dengan kriteria S2 (layak) dan persentase terendah yaitu variabel kondisi jalan sebesar $54 \%$ dengan kriteria S3 (cukup). Kondisi jalan yang sempit, terjal, dan berlumpur menyulitkan pengunjung saat akan mengunjungi kawasan MMEP, khususnya pengunjung yang mengendarai kendaraan roda dua. Hal ini sesuai dengan pernyataan Yoeti (1997) dalam Gautama dan Sunarta (2011), yang mengemukkan bahwa jika suatu obyek tidak didukung aksesibilitas yang memadai maka obyek yang memiliki atraksi tersebut sangat susah untuk menjadi industri pariwisata, aktivitas kepariwisataan banyak tergantung pada tranportasi dan komunikasi karena faktor jarak dan waktu yang sangat mempengaruhi keinginan seseorang untuk melakukan perjalanan wisata. Penenlitian selanjutnya yang dilakukan Barus et al. (2012) di kawasan Danau Linting, juga menyatakan bahwa kriteria untuk kondisi jalan kategori sedang adalah tipe jalan aspal dengan lebar lebih dari lima meter. Menurut para pengunjung, kondisi yang kurang mendukung untuk aksesibilitas ini adalah jarak lokasi dari pusat kota yang tergolong dalam kategori buruk dengan jarak lebih dari 15 kilometer dan tidak adanya transportasi berupa angkutan umum yang langsung menuju Danau Linting. Waktu tempuh menuju Danau Linting sekitar 1-2 jam dari pusat kota Medan juga salah satu faktor yang merupakan hambatan karena para pengunjung menganggap waktu tempuhnya terlalu lama.

Hasil analisis terhadap parameter fasilitas persentase tertinggi yaitu variabel kondisi jalur tracking sebesar 79,5\% dan persentase terendah yaitu variabel ketersediaan fasilitas bersantai atau tempat duduk dan berkumpul sebesar 69,5\%, keduanya masuk dalam kriteria S2 (layak). Jumlah fasilitas bersantai/tempat duduk dan berkumpul belum cukup untuk menampung jumlah keseluruhan pengunjung pada hari libur, sebagian besar pengunjung yang datang berpasangan merasa kurang nyaman jika harus berbagi tempat duduk bersama pengunjung lain yang datang berpasangan maupun berkelompok. Hal ini sesuai denga penelitian yang dilakukan oleh Tricahyo dan Djatmiko (2014), mengemukakan bahwa pada dasarnya produk berupa fasilitas duduk untuk kebutuhan ruang umum sebaiknya dibuat untuk memenuhi kebutuhan manusia sesuai dengan karakter dan budaya di tempat atau didaerah itu sendiri. Sarana duduk sebagai media yang memberikan fasilitas untuk duduk harus disesuaikan dengan kebutuhan dan karakter yang ada di kawasan tersebut.

Hasil penelitian kriteria kelayakan pengembangan kawasan hutan mangrove yang dilakukan melalui pengamatan kondisi lapangan dan data yang dikumpulkan selama penelitian, diperoleh penilaian rata-rata tiga parameter utama yaitu potensi sebagai obyek wisata, aksesibilitas, dan fasilitas masuk dalam kategori S2 (layak) untuk dikembangkan sebagai destinasi wisata alam mangrove. Penilaian kelayakan serupa dengan penelitian yang dilakukan oleh Wiharyanto (2007) yang menggunakan analisis kelayakan ekowisata dengan cara menjumlahkan hasil skoring. Parameter yang digunakan sebagian juga hampir serupa yaitu terdapat parameter daya tarik lokasi, aksesibilitas, sarana-prasarana penunjang, dan keamanan. Penelitian selanjutnya yang dilakukan oleh Khoiri et al. (2014) juga menggunakan penilaian kelayakan yang sama yaitu dengan cara perkalian bobot dan skor. Parameter yang digunakan dalam penelitian yang serupa yaitu meliputi kriteria ekologi. Berdasarkan analisis deskriptif menggunakan SPSS for Windows 16.00 maka dapat ditarik kesimpulan bahwa tendensi nilai yang paling mendekati mean adalah 73,3 dan nilai yang paling mendekati median adalah 73.0. Hal ini sesuai dengan hasil analisis kelayakan pada Tabel. 3 yang menyatakan bahwa hasil penilaian ratarata kelayakan wisata alam di MMEP adalah sebesar 73,65 termasuk dalam kriteria S2 (layak).

\section{KESIMPULAN}

\section{Kesimpulan}

Profil pengunjung MMEP didominasi oleh kalangan muda yang berusia 20-25 tahun dengan tingkat pendidikan lulusan Sekolah Menengah Atas. Sebagian besar pengunjung MMEP berasal dari kota Semarang dengan model kunjungan bersama pasangan.

Persepsi pengunjung mengenai objek wisata setelah melakukan kunjungan ke MMEP sebagian besar masih belum mengetahui fungsi dan manfaat mangrove. Hampir seluruh pengunjung menyatakan bahwa MMEP layak untuk dikembangkan sebagai kawasan wisata alam merasa tidak keberatan untuk biaya tiket masuk sebagai subsidi bibit mangrove.

Kelayakan MMEP berdasarkan nilai rata-rata tiga parameter utama yaitu potensi biofisik (ekologis), aksesibilitas dan fasilitas termasuk dalam kriteria S2 (layak) untuk dikembangkan menjadi destinasi wisata alam, kecuali parameter kemudahan transportasi dan kondisi jalan. 


\section{UCAPAN TERIMA KASIH}

Penulis mengucapkan terimakasih kepada Dr. Ir. Max Rudolf Muskanafola, M.Sc atas bimbingan dan arahannya dalam penyusunan jurnal ini.

\section{DAFTAR PUSTAKA}

Arisandi, MH., S. Surbakti dan Nurhasanah. 2014. Eksternalitas Penambangan Pasir Pantai Secara Tradisional terhadap Ekosistem Mangrove dan Sosial Ekonomi Masyarakat Pesisir di Kabupaten Merauke. Jurnal Manajemen Perikanan dan Kelautan. I (1). Program Pascasarjana Universitas Terbuka Jakarta.

Barus, SIP., P. Patana dan Y. Afifudin. 2012. Analisis Potensi Objek Wisata dan Kesiapan Masyarakat dalam Pengembangan Desa Wisata Berbasis Masyarakat di Kawasan Danau Linting Kabupaten Deli Serdang.

Black, R. 2000. Ecotourism and Education. Aeburg-Wodonga,NSW: (AU). Charles Sturt University Pr.

Firmansyah, A., F. Lestari dan Susiana. 2016. Identifikasi Potensi Sumberday Mangrove sebagai Pencadangan Kawasan Konservasi di Perairan Pantai Lola, Desa Gunung Kijang, Kabupaten Bintan, Kepulauan Riau. FIKP. UMRAH.

Gautama, IGGU dan N. Sunarta. 2011. Evaluasi Perkembangan Wisata Bahari di Pantai Sanur.

Ghozali, I. 2011. Aplikasi Analisis Multivariate dengan Program IBM SPSS 19 (Edisi kelima). Semarang : Universitas Diponegoro.

Hamali, AY. 2013. Pengaruh Motivasi terhadap Produktivitas Kerja : Studi Kasus pada PT X Bandung. Journal The WINNERS. XIV (2) : 77-86.

Keputusan Menteri Lingkungan Hidup No.201 tahun 2004. Kriteria Baku dan Pedoman Penentuan Kerusakan Mangrove.

Khoiri, F., B. Utomo dan I. Lesmana. 2014. Analisis Kelayakan Pengembangan Ekowisata Mangrove di Pantai Muara Indah Kecamatan Pantai Labu Kabupaten Deli Serdang.

Kustanti, A. dan R.F Yulia. 2011. Manajemen Hutan Mangrove. Bogor. PT. Penerbit IPB Press.

Narbuko, C. dan A. Achmadi. 2007. Metodologi Penelitian. Jakarta: Bumi Aksara.

Notoatmodjo, S. 2002. Metodologi Penelitian Kesehatan. Jakarta: Rineka Cipta.

Simanjuntak EO., M. Basyuni dan LAP. Putri. 2013. Keanearagaman Jenis dan Pendugaan Cadangan Karbon Tersimpan pada Hutan Sekunder dan Tambak di Desa Pulau Sembilan, Kecamatan Pangkalan Susu, Kabupaten Langkat Sumatera Utara.

Sitepu, AC., Yunasfi dan A. Muhtadi. 2015. Kajian Kesesuaian Ekowisata Mangrove di Pantai Putra Deli, Desa Dena Kuala, Kecamatan Pantai Labu, Kabupaten Deli Serdang, Provinsi Sumatera Utara.

Slamet, IWA., IN. Sudiarta dan IW. Suhardana. 2015. Persepsi Wisatawan terhadap Aksesibilitas dari Penelokan menuju Objek Wisata Toyabungkah Kecamatan Tingkamati Kabupaten Bangli. Jurnal IPTA. III (1). ISSN 2338 $-8633$.

Tricahyo, F dan M.D. Djatmiko. 2014. Perancangan Fasilitas Duduk di Ruang Terbuka Kota Bandung dengan Pencitraan Bandung sebagai Kota Kembang. (Studi Kasus Taman Cikapayang). Institut Teknologi Nasional Bandung.

Umami, Z. 2015. Social Strategy pada Media Sosial untuk Promosi Pariwisata Daerah Istimewa Yogyakarta. Jurnal Interaksi. IV (2) : 195-201.

Wiharyanto, D. 2007. Kajian Pengembangan Ekowisata Mangrove di Kawasan Konservasi Pelabuhan Tengkayu II Kota Tarakan Kalimantan Timur. Sekolah Pasca Sarjana IPB.

Yusiana, LS dan NNA. Mayadewi. 2016. Pengembangan Interpretasi Budaya guna Mendukung Program Pelestarian Tapak Arkeologi. Jurnal Arsitektur Lansekap. II (1) : $72-82$. 